\title{
Manajemen Parenting Berbasis Budaya Lokal Cirebon
}

\author{
Saifuddin \\ IAIN Syekh Nurjati Cirebon \\ Email: saifuddin@syekhnurjati.ac.id \\ Orcid Id: 0000-0002-5835-7286
}

\section{Asep Mulyana \\ IAIN Syekh Nurjati Cirebon \\ Email: asepmulyana@syeknurjati.ac.id}

\section{Siti Maryam Munjiat}

IAIN Syekh Nurjati Cirebon

Email: siti.maryam.munjiat@syekhnuriati.ac.id

Orcid ld: 0000-0002-5423-6962

\section{Imam Sibaweh}

IAIN Syekh Nurjati Cirebon

Email: Sibawehimam01@syeknuriati.ac.id

Orcid Id: 0000-0001-9762-2735

\section{Article received: 29 Desember 2020, Review process: 01 Februari 2021,} Article Accepted: 22 Maret 2021, Article published: 30 Maret 2021

\begin{abstract}
Parents as the main educators provide role models in every aspect of children's lives, but the current condition of parents is not able to provide exemplary education for children, parenting education provides basic knowledge to parents how to plan, implement, and evaluate parenting based on local culture in educating This study used qualitative methods with a naturalistic approach in observation and data collection, and the researchers themselves in this study as the main instrument. Observation by analyzing documents and monitoring the location and seeing the child's condition closely at the RA Baiturridwan Gebang and RA Tholaal Badr Gunung institutions Teak. The research discussion is divided into three aspects, namely: first, the parenting aspect is an important aspect for providing education to children, this parenting can be said to be a parent who plays a major role in creating education based on local wisdom. both aspects of educating children are an important part of education. The three Cirebon local cultures are important aspects that must be considered by all parties, especially parents and teachers, parents at the teacher's house when at school. Researchers conclude this study, as follows: In the aspect of educating children, many parents do not understand how to provide education to their children, especially when they get together with their families, and even when the time agreed by the family is not found. In the aspect of Cirebon's local culture, many families do not use the free language. In the parenting aspect, parents who do not carry out education in order to improve their quality to get parenting knowledge tend to ignore. In the parenting


aspect as an evaluation, parents should be fully involved to become the foremost teaching staff in the home.

\title{
Keywords: parenting, educating children, Cirebon local culture
}

\begin{abstract}
Abstrak
Orang tua sebagai pendidik utama memberikan keteladanan dalam setiap aspek kehidpan anak, tetapi kondisi saat ini orang tua belum mampu memberikan pendidikan keteladanannya bagi anak-anak, pendidikan parenting memberikan pengetahuan mendasar kepada orang tua bagaimana perencanaan, pelaksanaan, dan evaluasi parenting berbasis budaya local dalam mendidik anak-anak Penelitian ini menggunakan metode kualitatif dengan pendekatan naturalistic dalam observasi dan pengumpulan datanya, dan peneliti sendiri dalam penelitian ini sebagai instrumen utama.Observasi dengan menganalisasis dokumen dan memantau lokasi serta melihat keadaan anak dari dekat pada lembaga RA Baiturridwan Gebang dan RA Tholaal Badr Gunung Jati. Pembahasan penelitian dibagi pada tiga aspek, yaitu: pertama, aspek parenting merupakan aspek penting untuk memberikan pendidikan kepada anak-anak, parenting ini bisa dikatakan sebagai orang tua yang berperan besar dalam menciptakan pendidikan berbasis kearifan lokal. kedua aspek mendidik anak merupakan bagian penting dalam pendidikan. ketiga budaya lokal Cirebon merupakan aspek penting yang harus diperhatikan semua pihak, terlebih lagi orang tua dan guru, orang tua ketika di rumah guru ketika di sekolah. Peneliti menyimpulkan penelitian ini, sebagai berikut: Pada aspek mendidik anak banyak orang tua yang belum memahami untuk memberikan pendidikan kepada anak-anak mereka, terutama pada saat kumpul bersama dengan keluarga bahkan tidak ditemukan waktu yang disepakati oleh keluarga. Pada aspek budaya lokal Cirebon, banyak keluarga yang tidak menggunakan bahasa bebasan. Pada aspek parenting orang tua tidak melaksanakan pendidikan dalam rangka meningkatkan kualitasnya untuk mendapatkan ilmu parenting cenderung mengabaikan, Pada aspek parenting sebagai evaluasi orang tua seharusnya terlibat secara penuh untuk menjadi tenaga pengajar terdepan dalam rumah.
\end{abstract}

\section{Kata Kunci: parenting, mendidik anak, budaya lokal Cirebon}

\section{PENDAHULUAN}

Menjaga alam merupakan kewajiban setiap manusia. Manusia mendapatkan pendidikan harusnya diimbangi dengan memberi pengetahuan akan pentingnya keseimbangan alam agar ekosistem menjadi stabil. Pendidikan pengetahuan tentang alam sebaiknya diberikan sejak kecil, bukan tugas guru saja yang menyampaikan pengetahuan ini. Bahkan, orang tua yang bersinggungan dengan anak setiap hari juga harus memberikan pengetahuan tentang keseimbangan alam. Orang tua ada yang menyebutnya sebagai parenting memiliki peranan terbesar dalam membentuk masa depan generasi yang akan datang. Mendidik anak melalui peran orang tua memberikan solusi dari kerepotan pemerintah untuk mencerdaskan bangsa melalui pendidikan kepada orang tua. Jika pendidikan anak ini dilakukan oleh orang tuanya, maka kemajuan sebuah bangsa ada di depan mata (Vinayastri, 2015). (Kurniawan \& Hermawan, 2016) 
menyatakan bahwa parenting sebuah istilah yang cukup trend bagi kalangan pendidikan yang berarti memiliki pengertian bahwa mendidik seorang anak dari mulai di kandungan sampai kepada anak disebut sebagai orang dewasa. Pendidikan anak yang selama ini berpusat pada pendidikan formal harus segera bergeser pada orang tuanya sendiri, tidak lagi berharap pada sebuah lembaga pendidikan, terutama berkaitan dengan moralitas dan etikanya. Orang tua memiliki peranan yang sangat besar dalam mempengaruhi jiwa a na,kegagalan kebanyakan anak-anak biasanya bergantung pada pendidikan orang tua dalam menjadi keteladanan bagi anakanaknya, bukan bertumpu pada pendidikan formal. Kegagalan seorang anak bukan berorientasi pada sekolah formal, tetapi kegagalan seorang anak berorientasi pada kegagalan orang tuanya dalam mendidik (Ruli, 2020).

Sebagaimana yang diatur dalam undang-undang RI Nomor 35 tahun 2014 Tentang perubahan atas Undang-undang Nomer 23 tahun 2002 tentang perlindungan anak pasal 6 yang menyatakan bahwa setiap anak berhak untuk beribadah menurut agamanya, berpikir, dan berekspresi sesuai dengan tingkat kecerdasan dan usianya dalam bimbingan orang tua atau wali. Pasal tersebut memberikan gambaran bahwa orang tua berkewajiban untuk memberikan bimbingan kepada anak-anak mereka. Baik berkenaan dengan keagamaan, maupun arah gagasan pemikiran seorang anak agar orang tua mengetahui betul perkembangan seorang anak dari mulai dilahirkan sampai pada tingkat kedewasaan. Seorang anak akan buta dalam melangkahkan kakinya dengan suatu kebenaran keagamaan yang diyakini oleh orang tuanya. Anak tidak akan mengerti suatu perspektif kebaikan yang berlaku secara umum.

Bimbingan kepada seorang anak dapat membentuk kepribadian dalam menemukan karakter yang kuat bagi seorang anak setelah dewasa. Tetapi, banyak yang lupa bahwa parenting dalam memberikan pendidikan tidak melihat suatu kondisi dimana anak diberikan nasehat ataukah seorang anak dibiarkan karena waktunya yang belum tepat terutama ketika nasehat itu disampaikan kepada mereka. Ketepatan waktu dalam menasehati seorang anak merupakan saat dimana seorang anak membutuhkan nasehat (Munawar, 2017). Apalagi berkaitan dengan budaya lokal Cirebon dimana budaya lokal Cirebon menjadi parameter dengan kesantunan warga Cirebon. Namun, tampaknya sudah mulai kehilangan ruhnya. Terbukti, banyak warga Cirebon yang tidak berbahasa secara halus dan santun, bahkan bahasanya sudah mulai memudar. Seperti kula bade ningali rencang ingkang siweg uzur. Bahasa itu menjadi bahasa yang sangat halus namun banyak anak generasi sekarang tidak mengerti maksud dari bahasa itu. Padahal budaya dari aspek kebahasaan sudah seharusnya untuk dipertahankan (Ningrum, 2015).

Ungkapan bahasa merupakan karakter yang terbentuk dari seseorang semenjak dini, dan itupun tergantung bagaimana orang tua mendidiknya. Ada beberapa orang yang menggunakan bahasa binatang sebagai bahasa keseharian seperti kirik, ketek, kunyuk. Seperti dalam ungkapan tek, (ketek), sira arepan mendi?, jawabe: isun arep dolan ng arep nyuk (kunyuk). Bahasanya lokal tapi komunikasinya sangat kasar. Komunikasi yang jauh dari bahasa bebasan sangat jauh dari etika dan akhlak dalam kehidupan sehari-hari. Perkataan yang kasar tersebut sangat tidak diajarkan dalam nilai agama dan nilai kepercayaan, tidak dapat dibayangkan bagaimana komunikasi ini diberlakukan dalam kehidupan 
masyarakat. Apalagi perilaku hidup santun dan sopan kepada orang tua yang harus dihormati (Marát, Samsunuwiyati \& Kartono, Lieke, 2010). Bahkan, banyak remaja di Kabupaten Cirebon yang menjadi anggota genk motor, sebuah genk yang merusak generasi dengan kenakalannya. Genk ini tidak segan untuk membunuh orang lain yang dianggap menjadi rivalnya. Kenakalannya berada di luar batas kewajaran. Sehingga, banyak warga yang merasakan resah dengan kehadiran mereka. Mereka berbuat tindakan yang biadab dengan melakukan pengrusakan mall dan merusak beberapa kendaraan yang ada di pinggir jalan.

Kenakalan remaja bukan hanya sebatas pada persoalan keanggotaan menjadi anggota genk motor bahkan mereka melakukan perbuatan berminumminuman keras, pil dan narkoba sebagai makanan sehari-harinya. Tindakan semacam berada di luar budaya Cirebon yang sangat luhur. Lalu siapa yang disalahkan dengan persoalan ini, tetap saja yang bertanggung jawab adalah orang tua mereka. Maka manajemen parenting ini memberikan pengetahuan pendidikan kepada orang tua dalam mendidik anak-anak mereka dengan melihat budaya lokal Cirebon sebagai sebuah yang luhur. Sopian (Mitra Dialog, 2018) mengutip data dari BPS RI dan Bappenas, bahwa pada tahun 2013 penduduk Indonesia rentang usia 10 sampai 19 tahun berjumlah 44.241 .000 jiwa. Hal ini tentunya bisa menjadi aset bangsa yang berharga, apabila remaja dapat menunjukkan potensi dirinya. Secara umum permasalah remaja yang terjadi dewasa kini antara lain hubungan seks pra nikah hingga terjadi kehamilan yang tidak diinginkan, aborsi, kematian ibu akibat komplikasi kehamilan dan persalinan, pernikahan usia remaja, penularan virus HIV/AIDS, miras, narkoba dan sejenisnya. Permasalahan tersebut apabila tidak mendapat penanganan secara kompresehnsif, maka akan berdampak terhadap perilaku kehidupan kalangan remaja. Ajakan seseorang dengan kasih sayang membawa pada ajakan yang muda $\mathrm{h}$ diterima oleh semua lapisan masyarakat, meskipun tantangan dan hambatan selalu ada. Sebagaimana yang disampaikan oleh Rasulullah SAW dengan mengajak Ali bi Abi Thalib yang saat itu belum mencapai usia sepuluh tahun kemudian mengajaknya untuk beriman. Dia pun beriman kepada beliau dan mengikuti beliau secara diam-diam diperbukitan kota Mekkah bersembunyi dari keluarga dan bapaknya sendiri (Suwaid, 2010). Hal ini, membuat parenting menjadi penting bagi setiap orang tua dalam mendidik anakanak mereka. Termasuk bagaimana mendidik anak-anak mereka agar berkenalan dengan budayanya sendiri. Santun dalam bertutur kata, hormat kepada yang lebih tua, mencintai kepada yang mudah, memberikan pertolongan kepada yang membutuhkanya, membela kepada yang benar, menjunjung tinggi persamaan dan menghargai perbedaan.

Keteladanan pendidikan yang harus diberikan kepada anak-anak mereka dari orang tuanya. Bahkan, keteladanan itu harus diberikan pada saat anak-anak sudah mulai berpikir dengan sang idola, sementara yang menjadi idola dalam pendidikan adalah gurunya, dan guru yang terbaik adalah orang tuanya sendiri (Ni Gusti Ayu Made Yeni Lestari, 2019). Orang tua akan mengetahui perkembangan seorang anak semenjak dini. Namun, berbeda ketika orang tuanya sibuk hanya dengan berkutat pada persoalan kesibukannya sendiri. Persoalan anak yang seharusnya dididik oleh orang tuanya secara langsung namun terabaikan sehingga kurang perhatian dari orang tua, yang tidak menutup kemungkinan kurang mendapatkan perhatian dari orang tuanya. Orang tua 
sebagai idola dari seorang anak, tentunya akan mendapatkan perilaku yang diikuti oleh anak (Resiana Nooraeni, 2017). Sopian (Mitra Dialog, 2018) pemberian orang tua bukan hanya dari materi, melainkan harus menanamkan pendidikan moral. Misalnya, belajar agama, membentuk karakter, menerapkan dalam kehidupan dengan tanggung jawab."pada dasarnya pertumbuhan anak menjad tanggung jawab orang tuanya. Karena orang tua menjadi contoh dalam setiap aspek kehidupan, sehingga anak mendapatlkan perhatian yang lebih dari orang tuanya. Kebebasan untuk anak bukan berarti tanpa moralitas yang berlaku di masyarakat, tetapi harus mempertimbangkan semua aspek tersebut".

Setiap anak berhak untuk dapat hidup, tumbuh, berkembang dan berpartisipasi secara wajar sesuai dengan harkat dan martabat kemanusiaan serta mendapat perlindungan dari kekerasan dan diskriminasi (UU Nomor 23 Tahun 2002 tentang perlindungan anak pasal 4). Pasal ini menjamin hidup artinya bahwa setiap anak diberikan keleluasaan untuk hak hidupnya, tentunya hidup yang dimulai semenjak dilahirkan, bahkan semenjak masih berada dalam kandungan. Jaminan hidup yang dimiliki semenjak lahir tidak boleh untuk dibunuh atau diaborsi oleh orang tuanya. Tumbuh artinya anak semakin besar sampai dewasa diberikan keleluasaan untuk tumbuh seusuai dengan kenormalan masa usianya anak tersebut. Pertumbuhan setiap anak dari mulai masih bayi sampai sudah bisa berlari diberikan hak untuk tidak dihalangi pertumbuhannya. Berkembang artinya seorang anak diberikan hak dalam hidupnya berdasarkan peraturan perundang-undang. Berkembang secara pola piker dengan meningkatnya tingkat kedewasaan anak, meningkatnya pengetahuan anak, meningkatnya kesadaran anak sebagai bagian dari kehidupan, menyadari ada orang lain yang bukan dirinya, ada kakak, adik, dan orang tuanya, paman dan bibinya, om dan tantenya. Menyadari betul perbedaan yang ada, yang lunak bahkan yang keras. Semuanya bisa dibedakan dengan berkembangnya pemikiran seorang anak. Berpartisipasi artinya bahwa setelah anak mengalami perkembangan pemikiran dan perubahan perilaku dengan kematangan berpikirnya, maka anak berhak untuk berpartisipasi dalam kehidupan social masyarakatnya. Minimal berpartisipasi dalam keluarganya dengan membantu membersihkan halaman rumah, berpartisipasi dengan mencuci bajunya. Berpartisipasi memasak dan membersihakan kamar tidur. Berpartisipasi dengan secara lebih luas lagi dengan ikut pada kegiatan gotong royong warga, menjadi panitia kegiatan di tingkat desa, menjadi panitia pada kegiatan masjid dan keagamaan.

Mendisiplinkan anak-anak dengan melihat dengan kebiasaan perilaku pada anak-anak dengan kebiasaan yang wajib dan menjadi ritual. Misalnya jika berkaitan dengan pendidikan keagamaan maka rutinitas sholat menjadi terbiasa bahkan tidak menjadi beban bagi anak-anak. Berperilaku santun dan sopan bagi seorang anak dapat memberikan penjelasan bahwa mendisiplinkan dengan pendekatan akhlak. Menghormati orang yang lebih tua dan sayang kepada yang lebih muda. Hal inilah, yang menjadi pendekatan yang menentukan keberhasilan pendidikan anak dalam segi moral. Tentunya ini tergantung bagaimana orang tua menerapkan pendidikannya sebagai parenting dalam garda terdepan mendidik anak (Ganevi, 2018).

Dalam beberapa observasi pendahuluan misalnya di RA Tholaal Badr, dan RA Baituridwan, telah dilakukan kegiatan parenting yang pada umumnya 
dilakukan sebulan sekali, namun dirasakan belum maksimal dalam arti materi dan pelaksanaannya belum termanaj dengan baik serta hanya menggunakan budaya lokal sekedarnya dalam kegiatan tersebut, padahal menurut hemat peneliti khazanah budaya lokal Cirebon sangat kaya untuk dijadikan sumber inspirasi dan nilai-nilai luhur dalam mendidik anak usia Dini. Untuk itu, penelitian ini akan berfokus pada manajemen pemanfaatan budaya lokal sebagai materi yang baik dalam kegiatan parenting.

Penelitian ini akan membahas perencanaan, pelaksanaan, evaluasi menjadi analisis yang akan dikembangkan, termasuk tujuan dan manfaatnya. Penelitian ini sangat menarik yang tidak kalah dengan penelitian sebelumnya, seperti: penelitian Disertasi Emi Lindasari UPI Bandung (2016) yang menyatakan bahwa kesimpulan yang diperoleh dari penelitian,peneliti menemukan dua bentuk pr ogram parenting yang mana terdiri dari parenting formal yaitu seminar dan parenting rutin yaitu parent's day, dan penelitian Astria Mitha UI Jakarta (2012) yang menyatakan bahwa penelitian ini membantu orang tua untuk membantu dengan tepat bagi orang tua dalam mengasuh anak-anak mereka dan mengurangi stress. Orang tua dapat meningkatan level self-efficacy dimana self-efficacy tinggi cenderung menggunakan strategi problem-focused copying, sementara itu self efficacy rendah diasosiasikan dengan emotion-focused copying.

\section{METODOLOGI}

Penelitian ini menggunakan metode kualitatif dengan pendekatan natur alistik dalam observasi dan pengumpulan datanya, dan peneliti sendiri dalam penelitian ini sebagai instrumen utama. Metode ini digunakan karena mampu memberikan pemahaman yang mendalam dalam menganalisis dan mengembangkannya. Penelitian dilaksanakan tahun 2018 pada lembaga RA di kabupaten Cirebon pada studi kasus di RA Baiturridwan Gebang dan RA Tholaal Badr Gunung Jati. Teknik pengumpulan data penelitian dilakukan dengan observasi dengan meninjau lokasi penelitian dan menganalisis dokumen yang dimiliki oleh lembaga RA di kabupaten Cirebon pada studi kasus di RA Baiturridwan Gebang dan RA Tholaal Badr Gunung Jati dan wawancara dengan kepalas sekolah, guru, orang tua siswa pada RA di kabupaten Cirebon pada studi kasus di RA Baiturridwan Gebang dan RA Tholaal Badr Gunung Jati.

\section{HASIL DAN PEMBAHASAN Parenting}

Penelitian ini memberikan jawaban dari permasalahan anak-anak yang sudah banyak melupakan kearifan lokal, peranan yang besar dari orang tua adalah memberikan perhatian pendidikan bebasan sebagai bentuk penghormatan kepada orang tuanya sendiri. Namun, hal ini tidak banyak dari orang tua yang memberikan pendidikan bebasan kepada anak-anak mereka. Sebagaimana, pada penelitian di dua tempat, yaitu: di RA Tholaál Badr di Gunung Jati dan Baituridwan di Gebang. Selama melakukan wawancara dengan orang tua dan guru, sebagai berikut: misalnya saja pada pertanyaan peneliti: Bagaimana suasana lingkungan keluarga untuk mendukung komunikasi bebasan? Hampir kebanyakan orang tua dalam dua tempat itu tidak pernah menggunakan bahasa bebasan, ada yang menjawab tidak ada sama sekali, ada yang karena tidak bisa bahasa bebasan, 
meskipun ada memang ada bebarapa orang tua yang mampu menggunakan bahasa bebasan akan tetapi dukungan dari lingkungannya tidak ada, sehingga bahasa bebasan tidak pernah digunakan (Akhyadi \& Mulyono, 2018).

Lalu apa masalahnya terkait dengan pendidikan anak dengan menggunakan bebasan, kemudian pertanyaan selanjutnya oleh peneliti. Bagaimana sikap anak ketika mendapatkan perlakuan pendidikannya dengan bahasa bebasan dalam wawancara ini dijawab tidak mengerti karena mereka tidak diajarkan bebasantidak dibiasakan. Bahkan, ketika diberlakukan bahasa bebasan kebanyakan anak kebingungan. Tidak banyak yang menggunakan bebasan menjadikan anak kurang memahami bahasa bebasan itu. Pertanyaan yang kemudian oleh peneliti adalah nilai apa yang diberikan kepada anak dari orang tuanya. dijawab oleh orang tua bahwa nilai budi pekerti, sopan santun, nilai kedisplinan, nilai akhlak, nilai agaman, nilai kesopanan. Bahkan, ada juga orang tua dengan memberikan jawaban ucapan hebat-pintar, dan pelukan hangat, meskipun memang maksud dari pertanyaan itu belum dipahami oleh orang tua. Namun, peneliti memahami dalam jawaban pelukan kepada anak berarti kehangatan orang tua kepada anak, orang tua memberikan perhatian yang lebih untuk kasih sayang kepada anaknya tersebut.

Sebagaimana dalam sebuah teori yang dikemukakan oleh (Hartati, 2007) menyatakan bahwa prinsip meliputi tiga hal, yaitu: (1) berangkat dari yang dimiliki anak, (2) belajar harus menantang pemahaman anak, dan (3) belajar dilakukan sambil bermain. Prinsip belajar yang pertama terkaita dengan berangkat dari yang dimiliki anak, pengetahuan anak dari yang dimilikinya terutama dalam bahasa bebasan tidak dimilikinya. Dalam hal ini, anak seharusnya secara lebih untuk mendapatkan pengetahuan bahasa bebasan dalam pergaulan kehidupannya. Bahkan, dalam keseharian cenderung anak menggunakan bahasa Indonesia atau bahasa daerah yang kasar (Djaali, 2015). Daya dukung dalam pembelajaran bahasa bebasan ini sangat kurang terlihat ketika peneliti mengajukan pertanyaan bagaimana dukungan keluarga dan lingkungan dalam penggunaan bahasa bebasan tersebut. Jawaban dari orang tua dan guru tidak ada sama sekali untuk mendukung proses pembelajaran anak-anak dengan menggunakan bahasa bebasan tersebut (Susanto, 2015). Membangunkan anak tepat waktu terkadang terdapat problem dimana anak bermalas-malasan untuk bangun, apalagi jika di sekolah mengalami konflik dengan temannya, bahkan anak tidak akan berangkat ke sekolah. Anak cenderung untuk mengurung diri di rumahnya daripada berangkat ke sekolah. Pada saat seperti ini orang tua tampil untuk membujuknya dengan nasehat yang membuat anak semakin termotivasi.

Sebagaimana pada wawancara ketika apa yang harus dibangun ketika anak harus dimotivasi. Orang tua menjawab dengan penuh kesabaran, misalnya saja dengan jawaban yang semangat ya nak, atau juga dengan jawaban orang pinter akan selalu dihadapkan dengan cobaan. Semakin banyak cobaan justru akan menjadi sukses anakku.

Problem ketika anak menginjak remaja susahnya untuk diatur, ini artinya bahwa anak-anak seumuran PAUD harusnya diberikan pendidikan yang positif agar ketika menginjak remaja tidak susah diatur. Garda terdepan dalam membangun kedisiplinan berada pada bagaimana anak dididik semenjak dini. Misalnya, anak terbiasa dengan berlaku bersih maka seterusnya anak akan berlaku bersih. Sebaliknya, jika anak berlaku kotor maka anak akan selalu jorok. 
Parenting dalam hal ini peranan orang tua dalam mendidik anak, anak yang seperti apa dan bagaimana diberikan keleluasaan untuk berbuat. Namun, anak diberikan keleluasaan tersebut tidak berarti harus bebas tanpa aturan. Karena nilai yang dibangun semenjak kecil akan menjadi kebiasaan sampai dewasa. Ada peribahasa yang menyatakan endase diuculaken tapi sikile digeceli kepalanya diberikan kebebasan tapi kakinya dipegang. Artinya meskipun anak secara leluasa diberikan kesempatan untuk berkembang, namun etika dan moral anak jangan sampai kebablasan, sesuai dengan kerifan lokal yang sesuai dengan nilai-nila yang berlaku dalam kehidupan masyarakat.

\section{Mendidik Anak}

Peneliti memberikan analisisnya dalam mendidik anak berarti mempersiapkan generasi yang akan datang. Mempersiapkan generasi tidak semudah apa yang dibayangkan. Sebagaimana pendidikan itu hadir dalam rangka mempertahankan tujuan hadirnya sebuah Negara. Namun kenyataan di lapangan kehidupan justru banyak anak-anak kita yang terjebak dalam pergaulan bebas. Banyak anak-anak kita yang masuk dalam organisasi genk motor, banyak anakanak kita terjebak dalam kehidupan free seks, bahkan sudah ada beberapa anakanak kita yang terjebak dalam kehidupan lesbian, Gay, Biseksual dan Transgender (LGBT). Mengantisipasi persoalan kehidupan anak-anak yang sudah sedemikian parahnya, banyak anak-anak yang jauh dari nilai-nilai agama. Sudah semestinya penanaman nilai-nilai agama diterapkan semenjak dini. Wawancara yang dilakukan oleh peneliti untuk mendongkrak keprihatinan bersama adalah bagaimana anak diajarkan kesopanan banyak orang tua menjawab ketika masih anak-anak mudah diarahkan, tetapi setelah menginjak usai remaja banyak anakanak yang susah diatur. Anak susah diatur berarti berkaitan dengan bagaimana lingkungannya, pertanyaan seputar lingkungan ini berada dalam instrument kearifan lokal, peneliti mempertanyakan pada item nomer sebagai berikut, bagaimana pengawasan orang tua ketika anak bermain dengan lingkungannya. Namun, kebanyakan orang tua menjawab bebas yang penting anak bermain dengan waktu yang tepat. Hal ini, merupakan jawaban normative dari orang tua.

Peneliti melihat langsung dalam kehidupan lapangan anak, anak bermain kebanyakan tanpa pengawasan orang tua. Bahkan, ketika bergaul dengan teman sebayanya sangat ironis ketika di antara mereka terdapat konflik banyak menggunakan bahasa yang sangat kasar, seperti ketek, kirik. Pengawasan kebahasaan ini terjadi ketika anak ada problem dengan teman sebayanya. Kelalaian orang tua dalam hal ini, sangat wajar ternyata orang tua lebih cenderung untuk mengurusi rumahnya, bagi ibu-ibu cenderung memasak dengan membiarkan anaknya bermain, dan bagi bapak-bapak cenderung bekerja daripada mendidik anak dalam kesopanan bertutur kata. Peneliti kemudian mempertanyakan berapa lama anak bermain dengan lingkungannya, orang tua menjawab setelah pulang sekolah. Bahkan, setelah pulang sekolah anak-anak bermain secara leluasa dengan tidak memperhatikan waktunya yang secara maksimal digunakan. Banyak anak-anak yang tidak disiplin karena setelah pulan sekolah baru anak-anak pulang dari bermain itu menjelang magrib. Kearifan lokal yang sedang digaungkan oleh pemerintah saja dengan program magrib mengaji sering diabaikan oleh anak-anak.

Anak pulang sekolah menjelang maghrib, ini menunjukkan adanya pengabaian dari orang tua untuk belajar shalat dari mulai dhuhur sampai magrib. 
Anak pulang menjelang berarti membuat anak kecapean ketika anak terasa capek maka dalam hal ini anak malas untuk mengaji pada waktu magribnya. Banyak anak mendapatkan pendidikan dari lingkungannya yang notabene jauh dari pengawasan orang tuanya. Peneliti melihat secara nyata ada juga orang tua yang memberikan pengawasan kepada anak-anak mereka dengan tepat waktu. Setelah pulang sekolah anak yang betul-betul pengawasan orang tuanya, maka anak akan dicari oleh orang tuanya untuk diajak shalat berjamaah dan mengaji. Pada suatu lingkungan yang sama ada orang tua yang membiarkan anaknya bermain ada juga orang tua yang secara ketat menerapkan kedisiplinan dengan mengajaknya shalat berjamaah dan mengaji.

Penelitian ini sangat penting untuk melihat anak dari lingkungan yang sama dengan didikan yang berbeda, dengan pertanyaan bagaimana anak tersebut setelah menginjak remaja, lalu seperti apa dampaknya dalam kearifan lokalnya? Persoalan kenakalan remaja bahkan mungkin saja penelitian ini seharusnya membutuhkan waktu 15 tahun untuk melihat anak itu ke depannya. Tetapi, karena penelitian ini kejar tayang maka penelitian ini hanya seputar pada melihat faktafakta di lapangan dalam mendidik anak dengan metode yang diterapkan oleh orang tua. Bahkan, memungkinkan membutuhkan dana yang tidak sedikit karena dalam waktu yang lama setiap detiknya akan ada perubahan. Penelitian ini sangat menarik untuk dikembangkan secara lebih luas, agar bisa menjawab apa yang sebenarnya terjadi dalam kenakalan remaja itu.

Kembali lagi pada penelitian ketika peneliti melakukan wawancara dengan pertanyaan apakah orang tua membuat jadwal khusus untuk anak dalam membangun kedisiplinan? Jawaban dari orang tua Terdapat tiga jawaban tidak ada, kadang-kadang dan ya membuat jadwal. Ini menunjukkan bahwa tidak terdapat konsistensi dalam membangun kedisiplinan anak. Padahal dalam sebuah teori (Montessori, 2015) yang menyatakan bahwa disiplin harus muncul melalui kemerdekaan. Ini adalah sebuah prinsip besar yang sulit bagi para pengikut metode-metode sekolah umum untuk memahaminya (Lickona, 2013). Bagaimana mungkin seseorang akan menerapkan disiplin dalam sebuah kelas dari anak-anak yang bebas. Sungguh di dalam sistem kita, kita memiliki sebuah konsep disiplin yang sangat berbeda dari konsep disiplin yang diterima secara umum. Jika disiplin dilandaskan pada kemerdekaan atau kebebasan, maka disiplin itu sendiri harus bersifat aktif. Kita tidak menganggap bahwa seseorang dalam keadaan disiplin hanya ketika dia dibuat diam seperti orang bisu dan dibuat tak bergerak seperti orang lumpuh. Cara seperti ini bukan mendisiplinkan, tetapi menihilkan.

Itulah kebebasan yang terjadi pada wawancara dengan dua lembaga yang melibatkan orang tua, berada pada luar sekolah yang ingin menerapkan kedisiplinan dalam keadaan bebas. Disiplin dalam keadaan bebas atau berada di luar sekolah pada dasarnya tidak akan berhasil. Hanya saja, sebaiknya setelah selesai pulang dari sekolah untuk memberikan pendidikan di rumahnya. Pendidikan yang harus diberikan dalam kehidupan anak-anak adalah dengan kedisiplinan. Pendidikan ini penting agar anak dapat memperoleh kebiasaan hidup yang teratur. Terutama ketika bersentuhan langsung dengan kehidupan masyarakat. Keteraturan yang berlaku dalam kehidupan masyarakat menyangkut moralita, etika dan akhlak. Agar kedisiplinan ini dapat dipahami oleh anak-anak dengan memberikan pendidikan yang bersifat keteladanan dari orang tuanya dan guru-gurunya terlebih dari keteladanan Nabi SAW (Hairina, 2016). 
Penelitian ini memberikan penjelasan terkait dengan kedisiplinan ketika peneliti melakukan wawancara dengan memberikan pertanyaan, bagaimana respon anak ketika mendapatkan pendidikan kedisplinan dari orang tuanya? kemudian orang tua dari seorang anak yang bernama Dwi Adi Wijaya sekolah pada RA Tholaat Badr menjawab awalnya menolak tapi setelah dikasih pengertian akhirnya menurut. Wawancara ini menunjukkan seorang anak memang harus diberikan nasehat agar mau melaksanakan tugasnya sebagai orang yang bertanggung jawab. Peneliti memiliki pandangan bahwa ketika seorang anak jauh dari nasehat, maka akan mendapatkan perilaku yang jauh dari nilai-nilai kemasyarakatan, nilai keagamaan dan nilai yang berlaku dengan kehidupan masyarakat. Lalu peneliti mengajukan pertanyaan, bagaimana anak mendapatkan nasehat dari orang tuanya? dijawab oleh orang tuanya anak mendapatkan nasehat dari orang tuanya.

Menasehati anak seharusnya setiap waktu agar anak selalu ingat, pada dasarnya anak itu terlahir untuk selalu diberikan nasehat agar perjalanannya selalu lurus, nasehat ini merupakan bagian dari kedispilinan setiap individu. Pendidikan nasehat ini menjadi penting karena bentuk sederhana dari perhatian orang tua. Banyak orang tua yang menyalahkan arti perhatian, bahkan cenderung jauh dari perhatian itu sendiri. Misalnya banyak orang tua yang selalu memberikan sesuatu pada saat anak itu meminta, peneliti berasumsi bahwa justru hal ini menjerumuskan seorang anak untuk bermanja dan bergantung, tanp memberikan kegiatan lain untuk mencapainya. Kegiatan lain itu bisa saja, ketika anak itu meminta sesuatu agar diberikan tugas untuk membersihkan halaman terlebih dahulu, atau sesuatu yang lebih bermanfaat dalam mewujudkan kemandirian anak.

Penelitian kemudian membuat wawancara pertanyaan apa yang dilakukan anak ketika orang tua tidak ada di rumah, jawaban orang tuanya adalah, menangis atau mengamuk, ada juga bermain dengan permanainannya, bermain di rumah, bahkan ada yang men menjawab belajar sendiri. Jawaban yang variasi dari orang tua terkait dengan kemandirian anak, ketika orang tua tidak ada di rumah. Sangat penting dalam membangun kemandirian bagi anak, terutama ketika orang tuanya tidak ada di rumah, bahkan anak selayaknya diajak berdiskusi layaknya orang dewasa, berbicara dari hati ke hati, memberikan pengertian dan memahami keinginan anak, membiarkan anak yang memiliki keinginan dalam batas yang aneh. Sehingga, kita sebagai orang tua memahami betul bagaimana kondisi anak saat terpuruk maupun percaya diri. (Listyandari, 2011) menyatakan bahwa cobalah mengajak anak berbicara empat mata. Bahas masalah demi masalah secara matang, agar semakin mudah Anda dan buah hati menemukan jalan keluarnya. Keseriusan dan ketelatenan Anda dalam mendampingi buah hati dapat dilakukan dengan mengajaknya serius juga dalam menyikapi segala persoalan dirinya.

Pendekatan persuasif dalam memberikan nasehat kepada anak merupakan jalan yang baik untuk membentuk kepribadian anak. Kepribadian ini menjadi karakter tersendiri yang terbiasa dari seorang yang melakukan pembiasaan semenjak kecil. Banyak yang tidak menyadari bahwa kedisiplinan dengan nasehat merupakan bagian penting dalam mendidik anak merupakan salah satu mendidik anak (Sukaris1, Nur Fauziyah2, Andi Rahmad Rahim3, Syaiful4, Nurina Aprilianti5, 2020). Peneliti melihat ketiga hal tersebut sebagai gambaran yang 
terlihat pada teori, namun pada prakteknya banyak anak yang berumur 1-2 tahun sudah melihat orang lain dengan gerak-geriknya untuk ditiru. Anak menjadi plagiator ketika berumur tersebut, misalnya peneliti dalam kehidupan sehari-hari melihat anaknya sendiri yang berumur 1,5 tahun terbiasa dengan mengikuti gerakan shalat orang tuanya, meskipun sangat terbatas. Hanya saja, ketika bersujud si anak cenderung melakukan dengan telungkup.

Contoh tersebut menjadikan cerminan bahwa dalam praktek kenyataan di lapangan sangat berbeda dengan apa yang menjadi teori. Bahkan, anak akan menirukan ucapan orang lain meskipun dengan terbata-bata. Ada bahasa yang lucu dan menggemaskan dari anak yang berumur demikian. Namun, masih belum sempurna untuk bisa menirukan seperti orang dewasa pada umumnya. Peneliti melihat perkembangan kognitif ini merupakan daya dukung penelitian yang masih belum lengkap, jika mengkaji lebih dalam bahwa bermain praktis cenderung pada anak-anak 3-4 tahun, karena pola mereka dalam bermain dalam usia ini cepat bosan, artinya ketika permainan itu sudah bisa dibeli oleh orang tuanya anak-anak cenderung untuk tidak bermain. Bahkan, anak-anak usia ini ketika sudah membelinya permainan tidak dipegang dan tidak bermain dengan benda yang baru saja dibelinya, kemudian beralih kepada permainan yang lain.

Pada permainan simbolik misalnya, anak-anak cenderung mengabaikan ada yang perhatian dengan suatu simbol tertentu, tetapi anak cepat bosan, namun berbeda ketika suatu symbol itu selalu dibawa oleh orang tuanya, maka anak akan cenderung untuk dipakai dan dipamerkan kepada orang lain yang sebayanya. Bahkan anak cenderung untuk membanggakannya (Nur Ika Fatmawati, 2019). Bermain dengan aturan merupakan tantangan tersendiri bagi anak-anak untuk menjadi pemenang sebagai pemain yang jujur, jika anak-anak bermain dengan aturan ada kemungkinan semuanya termotivasi untuk berkompetensi. Bahkan, dengan aturan itu anak-anak semangat, kalau tidak ada aturan anak-anak tidak bisa bermain dengan baik, karena anak-anak akan berbuat seenaknya dan tidak fairplay.

Guru anak saya sewaktu di playgroup pernah menyarankan saya untuk memasukkan anak ke sanggar lukis, saya mencoba berulang kali menawarkan pada anak, tetapi dia tidak mau. Ya sudah, saya tidak memaksa. Memang dia pernah dua kali diminta sekolahnyauntuk ikut lomba mewarnai. Tapi, apa yang saya peroleh? Di arena perlombaan, para ibu tidak mau kalah mengikuti lomba dengan mencuri-curi membantu anak mereka. Tentu saja saya sangat tidak tertarik untuk menirunya. Hasilnya, anak yang menang yang dibantu ibunya. Sungguh, keterlaluan dan sangat tidak sportif. Saya lantas memutuskan tidak mengikutinya lagi (Listyandari, 2011). Peneliti sendiri sepertinya menemukan fenomena seperti itu, hanya saja dalam ruang yang berbeda. Peneliti melihat adanya ambisi orang tua untuk menyekolahkan anak-anak mereka seperti dirinya, sehingga orang tua terkadang ikut sekolah sebagai siswa. Orang tua yang menjadi anaknya, sehingga anak terdapat tuntutan yang sangat besar dari orang tuanya untuk menjadi seperti dirinya. Anak yang sekolah orang tua yang sibuk, anak yang bermain orang tua yang bertanya ke gurunya. Bahkan, yang lebih lucunya lagi mengunggulkan anaknya tersebut dengan tidak memperhatikan etika.

Ada istilah lain yang terkenal, orang tua sebagai siswa. Maksudnya orang tua menyibukkan dirinya menjadi anak-anak, pada kenyataan di lapangan apa yang menjadi ambisi orang tua tersebut tidak sesuai dengan apa yang menjadi 
keinginan anaknya. Anak berkeinginan bermain, orang tua berkeinginan yang lain. Memang betul anak harus dibiasakan dengan harapan orang tuanya semenjak kecil, tapi sebaiknya tidak harus untuk mengikuti ambisinya. Bahkan, anak dipaksa untuk mengikuti orang tuanya. padahal, secara alamiah anak akan mengikuti alur berpikir orang tuanya jika sudah mulai beranjak remaja.

\section{Budaya Lokal Cirebon}

Peneliti menganalisisnya dalam sebuah wawancara yang berkaitan dengan aspek yang berkaitan dengan nilai-nilai budaya tradisional, yaitu: (1) menari, (2) melukis dan (3) bahasa bebasan. Aspek menari, diawali dengan pertanyaan Apakah anak belajar seni yang mendukung kearifan local selain bebasan? Jawabanya adalah tidak. Ini menunjukkan hamper semua lembaga pendidikan tidak menggunakan seni tari dan seni melukis terkait dengan keterbatasan sumber daya manusia. Pada pelaksanaan penelitian ini terdapat kegiatan menari yang dipaksakan, dengan mengatasnamakan tarian Islam, namun kegiatan yang mendukung tarian tradisional tidak ada. Peneliti memperhatikan terdapat jenis tarian tradisional yang sudah hilang bahkan tidak ada sama sekali dalam kehidupan masa sekarang. Banyak anak-anak kita yang cenderung bermain gadget sehingga mereka tidak ada kesempatan untuk belajar dengan tarian tersebut. Sangat miris ketika Cirebon sebagai pusat pariwisata yang punya ciri khas sebagai kota budaya, kebudayaan Cirebon dengan jenis tari-tariannya sudah tidak dikenalkan kepada generasi selanjutnya (Diknas Jabar, 2015).

Penelitian ini sebenarnya lebih berfokus pada bahasa bebasa, bahasa bebasan merupakan pengantar kesopanan yang berlaku di dalam kehidupan masyarakat. Orang sopan adalah orang yang menggunakan bahasa bebasan dengan baik, kelayakan seorang anak adalah berkomunikasi dengan orang tuanya dengan bahasa bebasan. Bahasa yang menjadi cerminan dari sebuah keluarga, ketika keluarga itu melaksanakan bahasa bebasan dalam kehidupan sehari-hari berarti keluarga tersebut merupakan keluarga yang baik.

\section{PEMBAHASAN}

Peneliti membagi penelitian ini pada tiga aspek, yaitu: (1) aspek parenting, (2) aspek mendidik anak, dan (2) aspek kearifan lokal.

Pertama, Aspek parenting merupakan aspek penting untuk memberikan pendidikan kepada anak-anak, parenting ini bisa dikatakan sebagai orang tua yang berperan besar dalam menciptakan pendidikan berbasis kearifan lokal. Praktek komunikasi sangat bersentuhan langsung antara orang tua dan anak. Bahasa yang digunakan dalam keseharian sangat menunjang terciptanya komunikasi yang baik terutama dalam penggunaan bahasa bebasan. Parenting itu pada dasarnya orang tua mendidik anak-anak mereka. Pendidikan yang diberikan kepada anak-anak mereka bervariasi, ada yang dengan otoriter, ada yang acuh tak acuh, demokrasi. Orang tua yang mendidik anaknya dengan otoriter lebih banyak berhasil daripada yang lainnya. Tegas menjadi spirit orang tua yang memperhatikan anak-anak mereka dengan penuh tanggung jawab. Banyak anak yang merasa segan dengan pendidikan model ini, pendidikan yang diberikan menjadikan anak selalu berkordinasi dalam setiap sikap dan perilakunya. Dalam pendidikan Islam orang tua mendidik anak secara Islam (Ahmad Yani, Ery Khaeriyah, 2017). 
Namun, pada praktek kehidupan yang ditemukan peneliti sekaligus sebagai nara sumber. Memunculkan istilah proteksi anak atau sterilisasi anak, ini berdampak buruk bagi perkembangan anak, dimana anak keceriaanya dibatasi oleh sikap proteksi orang tuanya. Anak menjadi terbelenggu dengan perlakuan yang diberikan, sehingga anak dalam bersikap seperti ada rasa takut, muncul ketidakberanian seorang anak (Alwisol, 2015). Orang tua yang sangat proteksi terhadap anak-anaknya memberikan kesan menutup ruang gerak untuk bertindak secara leluasa. Bahkan, menimbulkan tidak percaya diri seorang anak. Anak cenderung mengurung dirinya di dalam kamar, atau tidak bisa bersosialisasi dengan teman-temannya. Padahal, hidup itu harus bersosialisasi dengan lingkungannya. Hal ini, ketika dilakukan orang tua sejak dini maka akan dampak buruknya sampai dewasa, tidak memiliki skill social (Wiranata, 2019).

Acuh tak acuh, orang tua yang mendidik anak-anak mereka dengan acuh tak acuh sangat berbahaya bagi perkembangan anak, anak yang tidak terkontrol dengan baik, maka dia akan hidup seperti tanpa aturan. Orang seperti ini memberikan pernyataan bahwa ia sebagai orang tua yang tidak bertanggung jawab. Anak dibiarkan begitu saja tanpa arahan yang benar akan berdampak bagi anak seperti kurang perhatian. Bahayanya ketika anak kurang perhatian maka anak akan mencari perhatiannya yang lain. Kurang perhatian dari orang tua akan mencari perhatian dari orang lain, biasanya kepada teman-temannya, tetapi perhatian kepada teman-temannya dilakukan dengan cara berbuat nakal, dan iseng. Bahkan, anak akan mengikuti trending yang terjadi pada masa itu. Seperti anak yang senang dengan bola, maka anak akan mengikuti pendukung yang lainnya yang menyukai bola dengan perilaku yang sama. Bahkan, anak yang senang bola rela untuk melakukan perbuatan membunuh orang lain, hanya persoalan orang lain tersebut tidak mendukungnya (Fahruddin1*, 2018).

Kedua, aspek mendidik anak merupakan bagian penting dalam pendidikan. Mendidik anak bukanlah hal yang mudah, namun perlu keseriusan semua pihak untuk ikut bertanggung jawab dalam menjalankan pendidikan itu sendiri. Kenakalan remaja yang sudah menjadi trenddiupayakan untuk dikikis secara optimal. Kenakalan remaja sangat meresahkan masayarakat terlebih lagi jika remaja tersebut terlibat dalam anggota genk motor banyak anak-anak yang terlibat perkelahian dan perampokan.

Mendidik anak tidak salah jika anak melakukan kesalahan dengan hukuman. Tentunya menghukum yang mendidik bukan menghukum yang menyakitkan baik secara fisik maupun secara mental. Efek jera bagi anak yang diberikan hukuman dengan tidak menyakitkan memberikan dampak anak tidak akan melakukannya lagi. Makanya dalam pendidikan Islam seorang anak yang sudah berumur tujuh tahun agar diajak shalat, namun jika anak yang sudah berumur sepuluh tahun maka pukullah (Anshor, M. U., \& Ghalib, 2010). Memberikan anak hukuman dengan memukul bukan memukul yang menyakiti anak sampai parah. Tetapi, memukul dengan benda yang tidak berbahaya dan itupun pada anggota badan yang kuat, seperti kaki. Anak yang disiplinkan menjadi kebiasaan, maka anak ketika melanggar kedisiplinan itu dia akan merasa bersalah. Anak yang merasa bersalah karena melakukan perbuatan tidak disiplin akan berupaya untuk tidak mengulanginya lagi, anak akan terus berpikir tentang perbuatannya. Apalagi jika anak tersebut semakin dewasa, maka tidak menutup 
kemungkinan rasa takut anak beralih kepada rasa tanggung jawab untuk menjaga aturan yang dibuat sejak kecil.

Kebiasaan berbuat baik bagi anak, akan terus dilakukan sampai dewasa, hal ini jika memberikan kedisiplinan sesuai dengan hukuman yang dilanggarnya. Anak akan sadar bahwa ia menjaga aturan itu buah dari kedisplinan yang diterapkan dalam lingkungan keluarganya. Anak yang terbiasa dengan shalat ketika kecil takut kepada orang tuanya karena dimarahi, berbeda ketika anak itu sudah menjadi dewasa rasa takutnya beralih kepada Tuhan (Dryden, 2000). Pada saat anak bermain, penting bagi orang tua untuk mengawasinya. Bermain dengan siapa, dimana bermainnya, kapan harus bermain, apa dan kenapa bermain. Membangun skill social dengan memberikan keleluasaan kepada anak, tanpa membatasi pergaulannya, namun tetap dalam pengawasan. Orang tua yang bijak akan memberikan nasehat kepada anak-anak mereka dengan memberitahukan mana teman yang bisa untuk bermain dan mana teman yang tidak boleh bermain dengannya (Astuti, 2013).

Ketiga, budaya lokal Cirebon merupakan aspek penting yang harus diperhatikan semua pihak, terlebih lagi orang tua dan guru, orang tua ketika di rumah guru ketika di sekolah. Guru bertanggung jawab dengan memberikan pendidikan yang bersifat global sementara orang tua memberikan pendidikan yang bersifat praktis. Orang tua hadir untuk melaksanakan program sekolah, dan sekolah hadir untuk merancang aktivitas kegiatan yang ada di rumah. Sesuai dengan pernyataan (Sahrudin, 2017) yang menyatakan tingkat kenakalan remaja di Cirebon sangat karena religious rendah. bahwa penting religius sangat diberikan kepada anak-anak dari orang tuanya. Dua aspek dalam kearifan lokal, yaitu: menari, dan bahasa bebasan. Menari dalam perkembangannya tidak diterapkan dalam lembaga pendidikan RA, namun pada kegiatan ekstrakurikuler kegiatan menari menjadi penting sebagai bentuk pelestarian kearifan lokal, semakin menghilang kegiatan tari menari pada lembaga pendidikan, banyak kita temukan kegiatan tari ini pada sanggar seni, namun itu dilakukan oleh orang dewasa.

Bahasa bebasan, semestinya diterapkan dalam kehidupan anak-anak, namun pada praktek kehidupan peneliti sendiri menemukan ada orang yang menggunakan bahasa ini untuk menunjukkan penghormatan kepada orang lain. Bahkan, ketika peneliti melakukan wawancara, cenderung menggunakan bahasa bebasan meskipun hanya sekali-kali. Penerapan pada anak-anak jarang digunakan dalam bahasa bebasan ini terutama pada lembaga pendidikan, hamper lembaga pendidikan dengan bahasa Indonesia. Sehingga keseharian dengan menggunakan bahasa Indonesia. Banyak yang sudah tidak menggunakan bahasa bebasan tidak menutup kemungkinan akan mengalami kehilangan bahasa bebasan untuk masa yang akan datang.

Peneliti menemukan penelitiannya bahwa ketiga aspek tersebut baik aspek parenting, mendidik anak dan kearifan lokal merupakan satu kesatuan yang integral yang tidak bisa dipisahkan satu sama lainnya. Penelitian yang utuh yang menjadi kokoh dalam fenomena pendidikan parenting di Indonesia khususnya di Cirebon sebagai trend teori yang sangat booming saat ini. Ketertarikan peneliti menggunakan penelitian parenting karena sehebat apapun sebuah lembaga pendidikan yang hebat adalah bagaimana orang tua mendidik anak-anak mereka. Pendidikan bukan berada pada lembaga pendidikan yang memiliki gedung yang 
menjulang tinggi, tetapi bagaimana orang tua berperan aktif dalam menerapkan moralitas dan membangun kearifan lokal yang harus dilestarikan sepanjang masa.

Hal ini, Seiring perkembangan zaman dan pesatnya arus informasi, bahasa daerah mulai tergerus bahasa lain yang dirasa lebih modern atau sedang menjadi tren, seperti bahasa asing. Masyarakat Cirebon mulai banyak yang enggan menggunakan bahasa daerahnya sendiri dalam kehidupan sehari-hari, terutama bahasa Cirebon halus/bebasa (Anis \& Hilmi, 2003).

\section{SIMPULAN}

Peneliti menyimpulkan penelitian ini, sebagai berikut: Perencanaan kegiatan parenting berbasis budaya lokal dalam mendidik anak-anak di RA seKabupaten Cirebon masih inssidental pada aspek parentingorang tua memberikan pendidikannya tidak berdasatkan jadwal yang dibuat oleh keluarga, tetapi berdasarkan waktu yang bersifat umum. Pada aspek mendidik anak banyak orang tua yang belum memahami untuk memberikan pendidikan kepada anak-anak mereka, terutama pada saat kumpul bersama dengan keluarga bahkan tidak ditemukan waktu yang disepakati oleh keluarga. Pada aspek kearifan lokal, banyak keluarga yang tidak menggunakan bahasa bebasan, Pelaksanaan kegiatan parenting berbasis budaya lokal dalam mendidik anak-anak di RA seKabupaten Cirebon.

Pelaksanaan pada aspek parenting orang tua tidak melaksanakan pendidikan dalam rangka meningkatkan kualitasnya untuk mendapatkan ilmu parenting cenderung mengabaikan. Pada aspek mendidik anak, pelaksaannya orang tua cenderung mengabaikan pendidikan nilai-nilai moral yang berlaku dalam masyarakat. Pada aspek kearifan lokal, banyak orang tua yang tidak melaksanakan kearifan lokal terutama bahasa bebasan.

Evaluasi kegiatan parenting berbasis budaya lokal dalam mendidik anakanak di RA se-Kabupaten Cirebon. Pada aspek parenting sebagai evaluasi orang tua seharusnya terlibat secara penuh untuk menjadi tenaga pengajar terdepan dalam rumah. Pada aspek mendidik anak, orang tua seharusnya mendidik anak dengan nilai-nila yang ada. Pada aspek kearifan lokal, banyak orang tua yang tidak memahami mana yang termasuk kearifan lokal, dan mana yang bukan kearifan lokal, terutama ketika menggunakan bahasa bebasan.

Peneliti menyarankan bahwa pada aspek parenting, mendidik anak dan kearifan local agar membuat perencanaan secara matang, melaksanakan sesuai dengan perencanaan dan mengevaluasinya untuk perbaikan, agar semua pihak ikut bertanggung jawab dalam membangun pendidikan parenting dengan mendidik kearifan lokal, terutama oleh lembaga pendidikan, pemerintah memberikan perhatian yang serius dalam memberikan pendidikan parenting agar secara maksimal orang tua memberikan pendidikannya kepada anak-anak mereka, dan semua pihak ikut mensosialisasikan kearifan lokal yang ada di Cirebon.

\section{DAFTAR PUSTAKA}

Ahmad Yani, Ery Khaeriyah, \& M. U. (2017). Implementasi Islamic Parenting Dalam Membentuk Karakter Anak Usia Dini Di Ra At-Taqwa Kota Cirebon. AWLADY: Jurnal Pendidikan Anak, 3(1). https://doi.org/10.24235/awlady.v3i1.1464

Akhyadi, A. S., \& Mulyono, D. (2018). Program Parenting dalam Meningkatkan 
Kualitas Pendidikan Keluarga (Program Pengabdian di Desa Karangpakuan, Kecamatan Darmaraja, Kabupaten Sumedang). Jurnal Abdimas, 1, 1-8.

Alwisol. (2015). Psikologi Kepribadian. In UMM Pers (kedua). UMM Pers.

Anis, M., \& Hilmi, A. (2003). Pemanfaatan Game Mobile pada Platform Android Berbasis Unity Game Engine untuk Melestarikan ahasa daerah Cirebon di Kalangan Generasi Muda. JAEI, 25-30.

Anshor, M. U., \& Ghalib, A. (2010). Parenting with Love: Panduan Islami Mendidik Anak Penuh Cinta dan Kasih Sayang: Panduan Islami Mendidik Anak Penuh Cinta dan Kasih Sayang. Mizania.

Astuti, H. P. (2013). Smart Parenting: Upaya Peningkatam Kemampuan Kognitif dan Kreativitas. Relkayasa, 11(2), 117-126.

Diknas Jabar. (2015). Blajar Basal an Sastra Cerbon-Dermayu. Kagungan Diknas Jabar.

Djaali. (2015). Psikologi Pendidikan. Bumi Aksara.

Dryden, G. dan V. J. (2000). Revolusi Belajar. The Learning Revolution. Belajar akan Efektif kalan Anda dalaam Keadaan Fun Jilid II. Diterjemahkan oleh Ahmad Baiquni. (2nd ed.). Kaifa.

Fahruddin1*, B. N. A. 1PG. (2018). Jurnal Pengabdian Magister Pendidikan IPA Pelatihan Program Parenting untuk Meningkatkan Profesionalisme Guru PAUD Di Kota Mataram Tahun 2018. Jurnal Pengabdian Magister Pendidikan IPA Original, 37-44.

Ganevi, N. (2018). Pelaksanaan Program Parenting bagi Orang Tua dalam Menumbuhkan Perilaku keluarga Ramah Anak(Studi Deskriptif di Pendidikan Anak Usia Dini Al-Ikhlas Kota Bandung). UPI, 1-11.

Hairina, Y. (2016). Prophetic Parenting sebagai Model Pengasuhan dalam Pembentukan Karakter Anak. Studia Insania, 4(1), 79-94.

Hartati, S. (2007). How To Be a Good Teacher and To Be a Good Mother. Enno.

Kurniawan, H. \&, \& Hermawan, R. (2016). Program Parenting untuk Membentuk Karakter Anak Usia Dini di Lembaga PIAUD. Jurnal PGRA, 1(1), 29-39.

Lickona, T. (2013). Mendidik untuk Membentuk Karakter. Bagaimana Sekolah dapat Mengajarkan Sikap Hormat dan Tanggung Jawab. Bumi Aksara.

Listyandari, R. (2011). Parenting Tiada Batas Kiat Mendidik Anak dengan Hati dan Otak. Gramedia.

Marát, Samsunuwiyati \& Kartono, Lieke, I. (2010). Perilaku Manusia Pengantar Singkat tentang Psikologi. Editor Ahli: Polhaupessy. Refika Aditama.

Montessori, M. (2015). Metode Montessori. Panduan untuk Guru dan Orang Tua Didik PAUd (Pendidikan Anak Usia Dini). Penerjemah: Ahmad Lintang Lazuardi. Pustaka Pelajar.

Munawar, B. \& R. (2017). Pendidikan Karakter. Pendidikan Menghidupkan Nilai untuk Pesantren, Madrasah dan Sekolah. Tha Asia Foundation.

Ni Gusti Ayu Made Yeni Lestari. (2019). Program Parenting untuk Menumbuhkan Kesadaran Keterlibatan Orang Tua di PIAUD. Jurnal Pendidikan Anak Usia Dini, 4(1), 8-17.

Ningrum, D. (2015). Kemerosotan Moral Di Kalangan Remaja: Sebuah penelitian Mengenai Parenting Styles dan Pengajaran Adab Diah Ningrum Sekolah Menengah Islam Terpadu (SMIT) AI Marjan. Unisia, xxxvii(82), 18-30.

Nur Ika Fatmawati. (2019). Literasi Digital, Mendidik Anak di Era Digital bagi 
Orang Tua Milenial. Madani, 11(2), 119-138.

Resiana Nooraeni. (2017). Implementasi Program Parenting Dalam Menumbuhkan Perilaku Pengasuhan Positif Orang Tua di PAUD Tulip Tarogong Kaler Garut. Jurnal Pendidikan Luar Sekolah, 13(2), 31-41.

Ruli, E. (2020). Tugas dan Peran Orang Tua dalam Mendidk Anak. Jurnal Edukasi Nonforman, 143-146.

Sahrudin. (2017). Peran dan Konsep Diri, Religiusitas, dan Pola Islami Terhadap Kecenderungan Perilaku Remaja di Cirebon. Syntax Literate, 2(1), 5062.

Sukaris1, Nur Fauziyah2, Andi Rahmad Rahim3, Syaiful4, Nurina Aprilianti5, K. Y. (2020). Seminar Parenting Model Pola Asuh Anak di Desa Karangsemanding. DedakasiMu, 2, 554-560.

Susanto, A. (2015). Teori Belajar dan Pembelajaran di Sekolah Dasar. Kencana.

Suwaid, A. (2010). Prophetic Parenting Cara Nabi SAW Mendidik Anak. Yogyakarta. ProU Media.

Vinayastri, A. (2015). Perkembangan Otak Anak Usia Dini. Jurnal IImiah Widya, 3.

Wiranata, I. G. L. A. (2019). Mengoptimalkan Perkembanga Anak Usia Dini. Jurnal Pendidikan Anak Usia Dini, 4(1), 48-56. 